\title{
Pengaruh Struktur Modal, Perputaran Modal Kerja, dan Ukuran Perusahaan Terhadap Nilai Perusahaan
}

\author{
Muhammad Rhamadan Setiawan ${ }^{1}$, Neneng Susanti ${ }^{2}$, Nugi Mohammad Nugraha ${ }^{3 *}$ \\ Fakultas Ekonomi \& Bisnis, Universitas Widyatama, Bandung, Indonesia \\ rhamadan.setiawan@widyatama.ac.id, neneng.susanti@widyatama.ac.id,
} nugi.mohammad@widyatama.ac.id

*Corresponding Author

Submitted: January 25, 2021

Accepted: February , 2021

Published: February 5, 2021

\begin{abstract}
This study aims to obtain empirical evidence regarding the effect of capital structure, working capital turnover and firm size on firm value. This research is focused on the property and real estate sub-sector companies listed on the Indonesia Stock Exchange for the period 2014-2018. The population in this study were all property and real estate sub-sector companies listed on the Indonesia Stock Exchange as many as 54 companies. The number of observations in this study were as many as 130 company annual reports with 26 research samples obtained by non-probability sampling method, namely purposive sampling technique. The type of data used is panel data which is a combination of time series and cross-section data. The analysis technique used in this research is multiple linear regression analysis. The results of the analysis show that partially the three independent variables, namely capital structure, working capital turnover and company size have a significant effect on firm value. Simultaneously, Capital Structure, Working Capital Turnover and Company Size have a significant effect on Firm Value. The adjusted R square value is $32.15 \%$ of the Firm Value in the property and real estate sub-sector companies listed on the Indonesia Stock Exchange can be explained by the Capital Structure, Working Capital Turnover and Company Size, while the remaining $67.85 \%$ is influenced by other variables. which were not examined in this study.
\end{abstract}

Keywords: Capital Structure; Firm Size; Firm Volume; Working Capital Turnover.

PENDAHULUAN

Berkembangnya pasar modal Indonesia masih belum bisa menandingi banyaknya investor yang berinvestasi pada investasi yang tidak memiliki bentuk fisik. Trend investasi yang selalu berkembang dan dicari oleh masyarakat Indonesia baik yang tua maupun yang muda salah satunya yaitu investasi dalam bentuk tanah atau properti. Berbeda dari investasi pada pasar modal, investasi pada properti dinilai lebih aman dibandingkan dengan investasi pada pasar modal (saham). Hal tersebut mengakibatkan industri pada sub sektor Property dan Real Estate terus berkembang pesat dan semakin banyak perusahaan yang ikut andil dalam pemanfaatan peluang tersebut (Endarwati, R. D., \& Hermuningsih, 2019). Investasi dalam bentuk tanah ataupun bangunan merupakan investasi yang dianggap paling aman karena memiliki fisik. Faktor lain yang menjadikan properti sebagai sasaran utama investasi yaitu harganya yang selalu naik. Harga yang selalu naik ini membuat banyak pihak tergiur untuk berinvestasi pada properti karena dapat memperkirakan keuntungan yang akan diperoleh.

Property dan Real Estate merupakan salah satu sub sektor di Indonesia yang memiliki peranan penting dalam pembangunan ekonomi negara. Deputi Gubernur Senior Bank Indonesia Mirza mengemukakan bahwa sektor property mendominasi perekonomian Indonesia dikarenakan sektor properti mampu menyerap tenaga kerja dalam jumlah yang besar. Sektor ini pun memiliki dampak berantai (multiplier effect) serta backward linkage yang berimbas cukup besar pada sektor-sektor lainnya. Oleh karena itu, sektor properti memiliki dampak yang signifikan dalam hal menarik dan 
mendorong sektor-sektor lainnya. Dampak lain dari sektor properti juga terasa terhadap perekonomian khususnya produk keuangan.

Nilai perusahaan merupakan persepsi investor terhadap tingkat keberhasilan perusahaan yang sering dikaitkan dengan harga saham. Harga saham yang tinggi membuat nilai perusahaan juga tinggi. Nilai perusahaan yang tinggi akan membuat pasar percaya tidak hanya pada kinerja perusahaan saat ini namun juga pada prospek perusahaan. Kusumajaya dalam Siregar (2019). Novrita dalam (Siregar, 2019). Berdasarkan teori-teori ahli nilai perusahaan akan terus digunakan investor untuk menggambarkan apakah perusahaan tersebut layak untuk diinvestasikan atau tidak. Nilai perusahaan yang baik dapat meyakinkan baik investor baru yang baru menanamkan modalnya ataupun investor yang sebelumnya sudah menanamkan modal dan akan menambah porsi saham yang akan dibelinya.

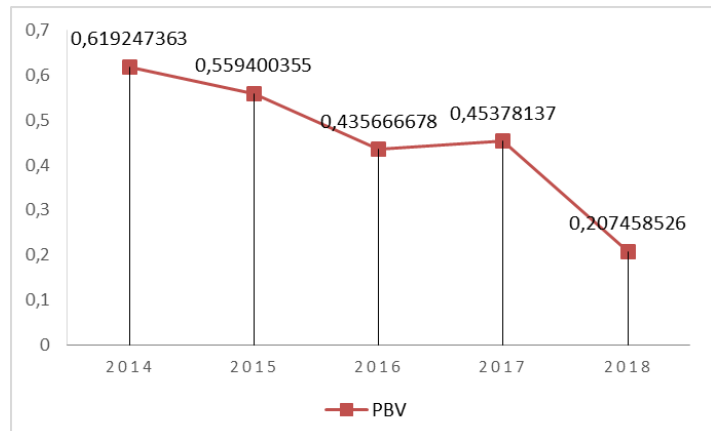

\section{Gambar 1. Pergerakan PBV Perusahaan Property dan Real Estate}

Sumber: Laporan Keuangan yang Diolah Juli 2020

Berdasarkan gambar diatas, dapat diketahui bahwa nilai perusahaan pada tahun 2014 hingga 2018 berfluktuatif. Nilai perusahaan property dan real estate secara trend mengalami penurunan, ini berbanding terbalik dengan kondisi perkembangan sub sektor property dan real estate yang sangat berkembang pesat. Kenaikan maupun penurunan nilai perusahaan tersebut dapat dipengaruhi oleh beberapa faktor diantaranya struktur modal, perputaran modal kerja dan ukuran perusahaan. Teori yang disebutkan oleh Prastuti dan Sudhiartha (2016) yang menyatakan bahwa semakin tinggi struktur modal maka semakin tinggi juga nilai perusahaan tersebut. Struktur modal sub sektor Property dan Real Esate pada tahun 2014-2018 mengalami pergerakan yang fluktuatif cenderung naik. Berbanding terbalik dengan nilai perusahaan yang mengalami pergerakan fluktuatif cenderung turun.

Tunggal dalam Indriyani (2018) mengemukakan bahwa indikasi pengelolaan modal kerja yang baik adalah adanya efisiensi modal kerja yang dapat dilihat dari perputaran modal kerja yang dimiliki dari aset kas diinvestasikan dalam komponen modal kerja (working capital turnover), perputaran persediaan (inventory turnover), dan perputaran piutang (receivable turnover). Perputaran modal kerja dimulai dari saat kas diinvestasikan dalam komponen modal kerja sampai saat kembali menjadi kas. Makin pendek periode perputaran modal kerja makin cepat perputarannya, sehingga modal kerja semakin tinggi dan perusahaan makin efisien yang pada akhirnya rentabilitas meningkat. Pemaparan teori Tunggal ini tidak sesuai dengan fakta lapangan yang ditemukan, dimana pada tahun 2014-2018 perputaran modal kerja perusahaan sub sektor property dan real estate mengalami fase fluktuatif yang cenderung naik. Hal ini berbanding terbalik dengan nilai perusahaan yang mengalami fase fluktuatif cenderung menurun.

Menurut Pratama (2016) semakin besar ukuran perusahaan akan mempengaruhi keputusan manajemen dalam memutuskan pendanaan apa yang akan digunakan oleh perusahaan agar keputusan pendanaan dapat mengoptimalkan nilai perusahaan. Pemaparan teori Pratama ini tidak sesuai dengan fakta lapangan yang ditemukan, dimana ukuran perusahan di sub sektor property dan real estate pada periode 2014-2018 mengalami fase fluktuatif yang cenderung naik. Hal ini berbanding terbalik dengan nilai perusahaan yang mengalami fase fluktuatif cenderung menurun.

Adanya perbedaan antara teori dan kenyataan di lapangan membuat peneliti tertarik untuk melakukan penelitian ini. Penelitian ini dibuat karena adanya ketidakpastian hasil pada penelitian- 
penelitian sebelumnya. Penelitian ini dilakukan untuk mengetahui apakah struktur modal, perputaran modal kerja dan ukuran perusahaan berpengaruh terhadap nilai perusahaan.

\section{STUDI LITERATUR}

Menurut Brigham (2011) struktur modal adalah perbandingan atau imbangan pendanaan jangka panjang perusahaan yang ditunjukan oleh perbandingan hutang jangka panjang terhadap modal sendiri. Pemenuhan kebutuhan dana perusahaan dari sumber modal sendiri berasal dari modal saham, laba ditahan, dan cadangan. Jika dalam pendanaan perusahaan yang berasal dari modal sendiri masih mengalami kekurangan (defisit) maka perlu dipertimbangkan pendanaan perusahaan yang berasal dari luar, yaitu hutang (debt financing). Namun dalam pemenuhan kebutuhan dana, perusahaan harus mencari alternatif-alternatif pendanaan efisien. Pendanaan yang efisien akan terjadi bila perusahaan mempunyai struktur modal yang optimal. Sedangkan menurut Sutrisno (2013) struktur modal merupakan pembelanjaan permanen yang mencerminkan perimbangan antara hutang jangka panjang dengan modal sendiri baik dari sumber internal maupun eksternal. Rasio yang digunakan untuk menghitung struktur modal dipenelitian ini adalah Debt to Equity Ratio (DER) dengan rumus sebagai berikut:

$$
\text { DER }=\frac{\text { Total Debt }}{\text { Total Equity }} \times 100 \%
$$

Menurut Kasmir (2014) perputaran modal kerja adalah salah satu rasio untuk mengukur atau menilai keefektifan modal kerja perusahaan selama periode tertentu. Perputaran modal kerja merupakan perbandingan antara penjualan dengan modal kerja bersih. Dimana modal kerja bersih adalah aktiva lancar yang dikurangi dengan utang lancar. Rasio perputaran modal kerja ini diukur dengan membandingkan penjualan dengan modal kerja atau dengan modal kerja rata-rata dan menunjukkan seberapa banyak perputaran penjualan perusahaan selama periode tertentu. Dalam penelitian ini, penulis menggunakan rasio perputaran modal kerja (working capital turnover) untuk mengetahui seberapa banyak perusahaan dalam menghasilkan penjualan yang disebabkan dengan perputaran modal kerja. Formula untuk menghitung Working Capital Turnover (WCT) sebagai berikut:

$$
\text { Working Capital Turnover }=\frac{\text { Penjualan Bersih }}{\text { Aktiva Lancar }- \text { Kewajiban Lancar }}
$$

Menurut Nugraha (2019) ukuran perusahaan adalah suatu skala yang dapat mengklasifikasikan perusahaan menjadi perusahaan besar ataupun perusahaan kecil menurut berbagai cara (seperti total aktiva atau total aset perusahaan, nilai pasar saham, rata-rata tingkat penjualan, dan jumlah penjualan). Perusahaan yang memiliki total aset besar menunjukkan bahwa perusahaan tersebut telah mencapai ke dalam tahap dewasa (Widajatun, 2020), dimana dalam tahap ini arus kas perusahaan sudah positif dan dianggap memiliki prospek yang baik dalam jangka waktu yang lebih lama, selain itu mencerminkan perusahaan relatif lebih stabil dan lebih mampu menghasilkan laba dibanding perusahaan dengan total aset yang lebih kecil (Alicia, 2020; Febriana, 2016). Rumus untuk mengukur ukuran perusahaan adalah sebagai berikut:

\section{Ukuran Perusahaan = Logaritma Natural Total Aktiva}

Nilai perusahaan didefinisikan sebagai nilai pasar karena nilai perusahaan dapat memberikan kemakmuran pemegang saham secara maksimum apabila harga saham meningkat (Brigham, E. F., \& Houston, 2011). Menurut Gitman (2012) nilai perusahaan adalah nilai actual per lembar saham yang akan diterima apabila aset perusahaan di jual sesuai harga saham. Semakin tinggi harga suatu saham, maka setiap lembar kepemilikan saham menjadi semakin bernilai dan semakin tinggi keyakinan investor akan return yang bisa didapat. Hal ini menjadi dasar tercapainya salah satu tujuan perusahaan yaitu memaksimumkan kemakmuran pemengang saham. Nilai perusahaan merupakan presepsi investor terhadap tingkat keberhasilan perusahaan perusahaan yang terkait erat 
dengan harga sahamnya (Soebiantoro, 2007). Nilai perusahaan juga merupakan harga dari sebuah perusahaan jika perusahaan tersebut akan dijual (Sihombing, 2020). Dalam penelitian ini untuk mengukur nilai perusahaan digunakan Price Book Value (PBV) yang merupakan rasio antara harga saham dengan nilai buku per lembar saham. Rumus Price Book Value (PBV) sebagai berikut:

$$
\mathrm{PBV}=\frac{\text { Market price per share }}{\text { Book value per share }}
$$

Penelitian terdahulu digunakan sebagai dasar dalam penyusunan penelitian. Tujuannya untuk mengetahui hasil yang telah dilakukan oleh peneliti terdahulu, sekaligus sebagai perbandingan dan gambaran yang dapat mendukung kegiatan penelitian berikutnya yang sejenis. Menurut Chasanah (2018) dalam penelitiannya yang berjudul "Profitabilitas, Struktur Modal dan Likuiditas pengaruhnya terhadap Nilai Perusahaan pada Perusahaan Real Estate yang listed di BEI tahun 2012-2015" hasilnya menunjukkan bahwa struktur modal secara parsial berpengaruh positif terhadap nilai perusahaan. Kemudian menurut Siregar (2019) dalam penelitiannya yang berjudul "Pengaruh Profitabilitas, Ukuran Perusahaan, Kebijakan Dividen, Dan Struktur Modal Terhadap Nilai Perusahaan Pada Perusahaan Manufaktur Yang Terdaftar Di BEI" hasilnya menunjukkan bahwa ukuran perusahaan secara parsial berpengaruh positif terhadap nilai perusahaan dan struktur modal secara parsial berpengaruh negatif terhadap nilai perusahaan. Selanjutnya penelitiaan yang dilakukan oleh Indriyani (2018) dengan judul "Pengaruh Perputaran Modal Kerja Dan Net Profit Margin (NPM) Terhadap Nilai Perusahaan Dengan Profitabilitas Sebagai Variabel Moderating Pada Perusahaan Farmasi Yang Terdaftar Di Bursa Efek Indoneisa" menunjukkan hasil bahwa perputaran modal kerja secara parsial berpengaruh negatif terhadap nilai perusahaan. Kemudian menurut Agusentoso (2017) dalam penelitiannya yang berjudul "Pengaruh Struktur Modal, Perputaran Modal Kerja dan Profitabilitas Terhadap Nilai Perusahaan (PBV)" menjelaskan bahwa struktur modal dan perputaran modal kerja secara parsial berpengaruh positif terhadap nilai perusahaan. Yang terakhir dalam penelitian yang berjudul "Capital Structure And Firm Size on Firm Value Moderated by Profitability" yang dilakukan oleh Hirdinis (2019) menunjukkan hasil bahwa struktur modal secara parsial berpengaruh positif terhadap nilai perusahaan dan ukuran perusahaan berpengaruh terhadap nilai perusahaan.

Hipotesi dalam penelitian ini adalah sebagai berikut:

H1: Struktur Modal berpengaruh terhadap Nilai Perusahaan.

H2: Perputaran Modal Kerja berpengaruh terhadap Nilai Perusahaan.

H3: Ukuran Perusahaan berpengaruh terhadap nilai perusahaan.

H4: Struktur Modal, Perputaran Modal Kerja dan Ukuran Perusahaan berpengaruh terhadap Nilai Perusahaan.

\section{METODE}

Metode penelitian yang dilakukan merupakan penelitian kuantitatif (Angelina, 2020; Ayunitha, 2020). Penelitian kuantitatif ini merupakan salah satu metode penelitian yang menguji data berupa angka-angka dan menggunakan statistik (Nariswari, 2020; Sugiyono, 2017). Penelitian ini dilakukan untuk mengetahui pengaruh variabel bebas berupa struktur modal, perputaran modal kerja dan ukuran perusahaan terhadap nilai perusahaan yang merupakan variabel terikat pada perusahaan sub sektor property dan real estate yang terdaftar di Bursa Efek Indonesia periode 2014-2018. Penelitian menggunakan data panel (Nugraha, 2020; Widajatun, 2019), yaitu gabungan data time series dan data crossectional karena membandingkan antar perusahaan pada seluruh perusahaan sub sektor property dan real estate yang terdaftar di Bursa Efek Indonesia selama 5 tahun. Data yang digunakan adalah data sekunder yang didapat dari situs resmi Bursa Efek Indonesia, yaitu www.idx.co.id yang berupa laporan keuangan yang sudah diaudit, dan annual report perusahaan. Informasi lainnya yang didapat oleh peneliti diperoleh dari buku, internet, makalah, jurnal keuangan yang menyangkut dengan objek yang diteliti oleh peneliti. Populasi dalam penelitian ini adalah seluruh perusahaan sub sektor property dan real estate yang terdaftar di Bursa Efek Indonesia yang berjumlah 54 perusahaan. Teknik nonprobability sampling dalam penelitian ini adalah purposive sampling. Sampel dari penelitian ini sebanyak 26 perusahaan, dan 
jumlah observasi adalah 130, karena penelitian dilakukan selama kurun waktu 5 tahun. Tehnik analisis data yang digunakan adalah analisis deskriptif verifikatif (Octavia, 2020; Susanti, 2020). Analisis data yang digunakan adalah analisis regresi berganda. Untuk mempermudah pengelolaan data, peneliti menggunakan bantuan software Eviews versi 9 untuk menghasilkan data dari beberapa uji seperti : Uji Asumsi Klasik, Uji Normalitas, Uji Multikolinieritas, Uji Heteroskedastisitas, Uji Autokorelasi, Uji Regresi Berganda, dan Uji Hipotesis.

\section{HASIL}

Uji Normalitas bertujuan untuk mengetahui apakah masing-masing variabel berdistribusi normal atau tidak (Wijaya, 2020).

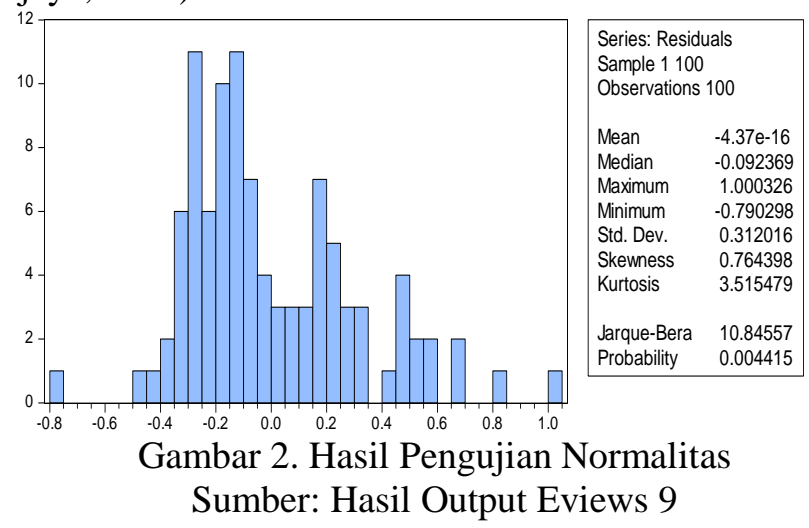

Berdasarkan gambar 2. hasil uji normalitas data menunjukkan bahwa nilai Jarque-Bera sebesar 10,84557 lebih besar dari 2 (dua) dan nilai probabilitas sebesar 0,004415 lebih kecil dari tingkat kekeliruan yaitu 0,05 atau 5\%. Dapat disimpulkan bahwa penelitian menunjukan model regresi tidak berdistribusi normal. Menurut Ghozali (2011) jika ukuran observasi besar melebihi dari 100 sampel maka dapat mengabaikan hasil dari uji normalitas data.

Uji Multikolinearitas dilakukan dengan dengan menggunakan VIF dengan kriteria jika nilai VIF suatu variabel bebas > 10, maka dapat disimpulkan bahwa variabel bebas tersebut terjadi multikolinearitas (Amalia, 2020).

Tabel 1. Hasil Uji Multikolinearitas

\begin{tabular}{cccc}
\hline Variable & Coefficient Variance & Uncentered VIF & Centered VIF \\
\hline C & 0.248781 & 247.7986 & NA \\
\hline DER & 0.018500 & 15.23976 & 2.967616 \\
\hline WCTO & 0.021488 & 15.46295 & 2.835284 \\
\hline SIZE & 0.030642 & 261.6230 & 1.096330 \\
\hline \multicolumn{5}{c}{ Sumber: Hasil Output Eviews 9} &
\end{tabular}

Berdasarkan Tabel 1. dapat diketahui bahwa nilai centered variance inflation factor (VIF) menunjukan nilai masing-masing variabel tidak lebih dari 10 atau $<10$. Oleh karena itu, dapat disimpulkan bahwa tidak ada multikolinearitas antara variabel independen dalam model regresi.

Penelitian menggunakan Uji-White dan hasil uji heteroskedastisitas sebagai berikut:

Tabel 2. Hasil Uji Heteroskedastisitas

Heteroskedasticity Test: White

\begin{tabular}{|c|c|c|c|}
\hline F-statistic & 7.486185 & Prob. F(9,90) & 0.0000 \\
\hline Obs*R-squared & 42.81200 & Prob. Chi-Square(9) & 0.5680 \\
\hline Scaled explained SS & 49.62478 & Prob. Chi-Square(9) & 0.5680 \\
\hline
\end{tabular}

Sumber: Hasil Output Eviews 9

Tabel 2. menunjukan nilai probabilitas Obs*R-Squared yang dihasilkan sebesar 42.81200 atau 
Prob. Chi-Square =0,5680 dibandingkan dengan tingkat signifikansi 0,05 maka 0,5680 > 0,05; sehingga dapat disimpulkan bahwa tidak terdapat gejala heterokedastisitas.

Model regresi yang baik adalah regresi yang bebas dari autokorelasi (Nugraha, 2020). Salah satu cara untuk mendeteksi ada tidaknya autokorelasi adalah dengan uji Durbin-Watson (DW).

Tabel 3. Hasil Uji Autokorelasi

\begin{tabular}{lcll}
\hline R-squared & 0.342151 & Mean dependent var & 0.344675 \\
\hline Adjusted R-squared & 0.321593 & S.D. dependent var & 0.384693 \\
\hline S.E. of regression & 0.316854 & Akaike info criterion & 0.578427 \\
\hline Sum squared resid & 9.638058 & Schwarz criterion & 0.682633 \\
\hline Log likelihood & -24.92133 & Hannan-Quinn criter. & 0.620601 \\
\hline F-statistic & 16.64336 & Durbin-Watson stat & 1.972818 \\
\hline Prob(F-statistic) & 0.00000 & & \\
\hline & Sumber: Hasil Output Eviews 9
\end{tabular}

Sumber: Hasil Output Eviews 9

Tabel 3. hasil uji autokorelasi menunjukkan bahwa nilai Durbin-Watson stat (DW) sebesar 1.972818. Jumlah observasi $(n)=130$, jumlah variabel penelitian $(k)=3$ dan tingkat signifikansi 0,05 didapat nilai $\mathrm{dl}=1,6131$; nilai $\mathrm{du}=1,7364$; dan nilai 4-du $=2,2636$, dibandingkan dengan nilai DW yang dihasilkan, maka diperoleh hasil bahwa $\mathrm{dl}<\mathrm{dw}<(4-\mathrm{dU})$ atau $1,6131<1.972818$ $<2,2636$; dapat disimpulkan bahwa tidak ada autokorelasi pada variabel dependen.

Metode analisis yang digunakan adalah analisis regresi data panel, karena data yang digunakan merupakan gabungan cross-section dan time series (Susyana, 2021; Zulganef, 2018). Hasil perhitungan analisis regresi data panel disajikan dalam tabel berikut:

Tabel 4. Hasil Uji Regresi Data Panel

\begin{tabular}{ccccc}
\hline Variable & Coefficient & Std. Error & t-Statistic & Prob. \\
\hline C & 1.497004 & 0.498780 & 3.001333 & 0.0034 \\
\hline DER & 0.701327 & 0.136014 & 5.156288 & 0.0000 \\
\hline WCTO & 0.531475 & 0.146587 & 3.625660 & 0.0005 \\
\hline SIZE & 0.574184 & 0.175047 & 3.280159 & 0.0014 \\
\hline
\end{tabular}

Sumber: Hasil Output Eviews 9

Berdasarkan hasil analisis regresi pada Tabel 4. maka diperoleh suatu persamaan regresi sebagai berikut:

$$
\mathrm{Y}=1.497004+0.701327\left(\mathrm{X}_{1}\right)+0.531475\left(\mathrm{X}_{2}\right)+0.574184\left(\mathrm{X}_{3}\right)+\mathrm{e}
$$

Dari model regresi tersebut dapat dijelaskan bahwa:

1. Nilai konstanta pada persamaan memiliki nilai sebesar 1.497004. Jika variabel independen Struktur Modal $\left(\mathrm{X}_{1}\right)$, Perputaran Modal Kerja $\left(\mathrm{X}_{2}\right)$, dan Ukuran Perusahaan $\left(\mathrm{X}_{3}\right)$ dianggap konstan, maka besarnya variabel dependen Nilai Perusahaan (Y) akan bernilai sebesar 1.497004 .

2. Koefisien regresi Struktur Modal sebesar 0.701327, artinya apabila Perputaran Modal Kerja dan Ukuran Perusahaan bernilai konstan atau nol (0) maka Nilai Perusahaan mengalami kenaikan sebesar 0.701327 setiap kenaikan Struktur Modal.

3. Koefisien regresi Perputaran Modal Kerja sebesar 0.531475, artinya apabila Struktur Modal dan Ukuran Perusahaan bernilai konstan atau nol (0) maka Nilai Perusahaan mengalami kenaikan sebesar 0.531475 setiap kenaikan Perputaran Modal Kerja.

4. Koefisien regresi Ukuran Perusahaan sebesar 0.574184, artinya apabila Struktur Modal dan Perputaran Modal Kerja bernilai konstan atau nol (0) maka Nilai Perusahaan mengalami kenaikan sebesar 0.574184 setiap kenaikan Ukuran Perusahaan.

Rancangan pengujian kecocokan model dengan menggunakan koefisien determinasi (Adjusted $R$ Square) pada intinya bertujuan untuk mengukur seberapa jauh kemampuan model dalam 
menerangkan variasi variabel dependen (Arikunto, 2005; Qotrotul, 2021). Hasil uji kecocokan model (goodness of fit).

Tabel 3. menujukkan bahwa nilai Adjusted R-squared sebesar 0.321593 atau 32,15\%. Hasil tersebut menunjukkan variabel Struktur Modal, Perputaran Modal Kerja dan Ukuran Perusahaan memberikan kontribusi sebesar 32,15\% terhadap Nilai Perusahaan dan sisanya sebesar $67,85 \%$ disebabkan oleh variabel independen lain yang tidak dibahas dalam penelitian ini.

Uji statistik F digunakan untuk menguji hubungan regresi secara simultan yang bertujuan untuk mengetahui apakah seluruh variabel independen secara bersama-sama memiliki pengaruh yang signifikan terhadap variabel denpenden (Nuryaman \& Veronica, 2015; Supardi, 2021). Hasil uji F disajikan dalam tabel sebagai berikut:

Tabel 5. Hasil Uji F

\begin{tabular}{lcll}
\hline R-squared & 0.342151 & Mean dependent var & 0.344675 \\
\hline Adjusted R-squared & 0.321593 & S.D. dependent var & 0.384693 \\
\hline S.E. of regression & 0.316854 & Akaike info criterion & 0.578427 \\
\hline Sum squared resid & 9.638058 & Schwarz criterion & 0.682633 \\
\hline Log likelihood & -24.92133 & Hannan-Quinn criter. & 0.620601 \\
\hline F-statistic & 16.64336 & Durbin-Watson stat & 1.972818 \\
\hline Prob(F-statistic) & 0.000000 & & \\
\hline & Sumber: Hasil Output Eviews 9
\end{tabular}

Berdasarkan tabel 5. diperoleh nilai $\mathrm{F}_{\text {hitung }} 16.64336$ dan $\mathrm{F}_{\text {tabel }}$ sebesar 2,70 berarti $\mathrm{F}_{\text {tabel }}>\mathrm{F}_{\text {tabel }}$ yaitu $16.64336>2,70$ dan nilai Sig. yakni $0,000000<0,05$ maka $\mathrm{H}_{\mathrm{a}}$ diterima. Dapat disimpulkan terdapat pengaruh yang signifikan secara simultan dari Struktur Modal, Perputaran Modal Kerjan dan Ukuran Perusahaan terhadap Nilai Perusahaan.

Pengujian hipotesis parisal atau uji t digunakan untuk menguji hipotesis dalam penelitian, dengan menunjukan seberapa besar pengaruh dari masing-masing variabel independen terhadap variabel dependen (Susanti, 2021; Taohid, 2021).

Tabel 6. Hasil Uji t

\begin{tabular}{cccc}
\hline Variabel & t hitung & $\boldsymbol{\alpha}$ hitung & Keterangan \\
\hline DER & 5.156288 & 0.0000 & Signifikan \\
\hline WCT & 3.625660 & 0.0005 & Signifikan \\
\hline Size & 3.280159 & 0.0014 & Signifikan \\
\hline & Sumber: Hasil Output Eviews 9 &
\end{tabular}

Hasil uji hipotesis sebagaimana terlihat pada tabel 6. menunjukan bahwa Debt to Equity Ratio berpengaruh positif terhadap Nilai Perusahaan dengan nilai probabilitas $0,0000<0,05$.

Hasil uji hipotesis sebagaimana terlihat pada tabel 6. menunjukan bahwa Working Capital Turnover berpengaruh positif terhadap Nilai Perusahaan dengan nilai probabilitas 0,0005 < 0,05.

Hasil uji hipotesis sebagaimana terlihat pada tabel 6. menunjukan bahwa ukuran perusahaan berpengaruh positif terhadap Nilai Perusahaan dengan nilai probabilitas $0,0014<0,05$.

\section{PEMBAHASAN}

Hipotesis pertama dalam penelitian ini adalah struktur modal berpengaruh positif signifikan terhadap nilai perusahaan. Hasil penelitian menunjukan bahwa setiap kenaikan struktur modal suatu perusahaan yang diukur dengan debt to equity ratio dapat meningkatkan nilai suatu perusahaan. Struktur modal perusahaan adalah pembiayaan permanen yang terdiri dari hutang jangka panjang, saham preferen, dan modal pemegang saham. Jadi, struktur modal suatu perusahaan hanya merupakan sebagian dari struktur keuangannya. Struktur modal adalah perimbangan atau perbandingan antara jumlah hutang jangka panjang dengan modal sendiri. Oleh karena itu, struktur modal diukur dengan debt to equity ratio (DER). DER merupakan rasio yang digunakan untuk mengukur tingkat leverage (penggunaan hutang) terhadap total shareholder's equity yang dimiliki 
perusahaan. Semakin tinggi DER menunjukkan komposisi total hutang (jangka pendek dan jangka panjang) semakin besar dibandingkan dengan total modal sendiri, sehingga berdampak semakin besar beban perusahaan terhadap pihak luar (kreditur).

Hasil penelitian ini sejalan dengan teori yang telah dijelaskan dan memiliki arah yang sama yaitu positif dan signifikan dengan penelitian yang dilakukan oleh Chasanah (2018), Endarwati (2019) yang mendukung bahwa struktur modal mempunyai pengaruh positif dan signifikan terhadap nilai perusahaan. Namun tidak didukung oleh penelitian yang dilakukan oleh Pratiwi (2016), yang menyatakan bahwa struktur modal tidak berpengaruh terhadap nilai perusahaan. Dengan demikian hipotesis $1\left(\mathrm{H}_{1}\right)$ diterima.

Hipotesis kedua dalam penelitian ini adalah perputaran modal kerja berpengaruh positif signifikan terhadap nilai perusahaan. Hasil penelitian menunjukan bahwa setiap kenaikan perputaran modal kerja suatu prtusahaan yang diukur dengan working capital turnover dapat meningkatkan nilai suatu perusahaan. Perputaran modal kerja berpegaruh terhadaap nilai perusahan karena perputaran modal kerja merupakan hal serius yang harus diperhatikan. Maka manajemen modal sangat dibutuhkan dalam mengelola perusahaan. Hal tersebut dapat mengantisipasi perusahaan mengalami gulung tikar. Mengolola modal kerja baik dapat berdampak baik terhadap nilai perusahaan jika nilai perusahaan merupakan nilai jual perusahaan identik harga saham tinggi. Nilai buku merupakan perkiraan nilai perusahaan untuk dilikuidasi. Nilai buku sendiri merupakan nilai aset perusahaan yang tercantum dalam laporan keuangan dapat dihitung dengan cara mengurangkan kewajiban perusahaannya dari asetnya.

Hasil penelitian ini sejalan dengan teori yang telah dijelaskan dan memiliki arah yang sama yaitu positif dan signifikan dengan penelitian yang dilakukan oleh Indriyani (2018) dan Agusentoso (2017) yang mendukung bahwa perputaran modal kerja mempunyai pengaruh positif dan signifikan terhadap nilai perusahaan. Namun tidak didukung oleh penelitian yang dilakukan oleh Hardiana (2019), yang menyatakan bahwa perputaran modal kerja tidak berpengaruh terhadap nilai perusahaan. Dengan demikian hipotesis $2\left(\mathrm{H}_{2}\right)$ diterima.

Hipotesis ketiga dalam penelitian ini adalah ukuran perusahaan berpengaruh positif signifikan terhadap nilai perusahaan. Hasil penelitian menunjukan bahwa setiap kenaikan ukuran perusahaan suatu perusahaan yang diukur dengan ln total assets dapat meningkatkan nilai suatu perusahaan. Ukuran perusahaan merupakan cerminan total dari aset yang dimiliki suatu perusahan. Perusahaan sendiri dikategorikan menjadi dua jenis, yaitu perusahaan berskala kecil dan perusahaan berskala besar. Ukuran perusahaan dianggap mampu memengaruhi nilai perusahaan. Ukuran perusahaan dapat terlihat dari total aset yang dimiliki oleh satu perusahaan. Ukuran perusahaan yang besar mencerminkan bahwa perusahaan tersebut sedang mengalami perkembangan dan pertumbuhan yang baik sehingga meningkatkan nilai dari suatu perusahaan. Nilai perusahaan yang meningkat dapat ditandai dengan total aktiva perusahaan yang mengalami kenaikan dan lebih besar dibandingkan dengan jumlah hutang perusahaan.

Hasil penelitian ini sejalan dengan teori yang telah dijelaskan dan memiliki arah yang sama yaitu positif dan signifikan dengan penelitian yang dilakukan oleh Siregar (2019) dan Hirdinis (2019) yang mendukung bahwa ukuran perusahaan mempunyai pengaruh positif dan signifikan terhadap nilai perusahaan. Namun tidak didukung oleh penelitian yang dilakukan oleh Pratiwi (2016) dan Suryandani (2018) yang menyatakan bahwa ukuran perusahaan tidak berpengaruh terhadap nilai perusahaan. Dengan demikian hipotesis $3\left(\mathrm{H}_{3}\right)$ diterima.

Hipotesis keempat dalam penelitian ini adalah struktur modal, perputaran modal kerja, dan ukuran perusahaan berpengaruh positif signifikan terhadap nilai perusahaan. Hasil uji statistik $\mathrm{F}$ pada tabel 4. menunjukkan nilai $F$ sebesar 16.64336 dengan tingkat signifikansi 0.000000 lebih kecil dari taraf signifikansi 0.05 (5\%). Hasil uji statistik F menunjukkan bahwa Struktur Modal, Perputaran Modal Kerja dan Ukuran Perusahaan memiliki pengaruh signifikan terhadap Nilai Perusahaan. Dengan demikian hipotesis $4\left(\mathrm{H}_{4}\right)$ diterima.

\section{KESIMPULAN}

Berdasarkan hasil penelitian dan pembahasan yang telah dilakukan dan didukung oleh beberapa landasan teori, maka pada bab ini peneliti mengambil beberapa kesimpulan dari hasil penelitian sebagai berikut: Struktur Modal secara parsial berpengaruh positif signifikan terhadap Nilai 
Perusahaan sub sektor property dan real estate periode 2014-2018. Jika posisi struktur modal berada di bawah titik optimal maka setiap penambahan hutang akan meningkatkan nilai perusahaan. Perputaran Modal Kerja secara parsial berpengaruh positif signifikan terhadap Nilai Perusahaan sub sektor property dan real estate periode 2014-2018. Mengelola modal kerja baik dapat berdampak baik terhadap nilai perusahaan jika nilai perusahaan Ukuran Perusahaan secara parsial berpengaruh positif signifikan terhadap Nilai Perusahaan sub sektor property dan real estate periode 2014-2018. Ukuran perusahaan yang besar mencerminkan bahwa perusahaan tersebut sedang mengalami perkembangan dan pertumbuhan yang baik sehingga meningkatkan nilai dari suatu perusahaan. Struktur Modal, Perputaran Modal Kerja dan Ukuran Perusahaan secara simultan berpengaruh positif signifikan terhadap Nilai Perusahaan sub sektor property dan real estate periode 2014-2018.

\section{REFERENSI}

Agusentoso, R. (2017). Pengaruh Struktur Modal, Perputaran Modal Kerja dan Profitabilitas Terhadap Nilai Perusahaan (PBV). Jurnal Pendidikan, Ekonomi Dan Bisnis, 1(4), 17-31.

Alicia, R., Putra, J., Fortuna, W., Felin, F., \& Purba, M. I. (2020). Pengaruh Growth Opportunity, Leverage dan Firm Size terhadap Cash Holding Perusahaan Properti dan Real Estate. Owner : Riset Dan Jurnal Akuntansi, 4(2), 322-329. https://doi.org/10.33395/owner.v4i2.219

Amalia, S., Fadjriah, N. E., \& Nugraha, N. M. (2020). The Influence of the Financial Ratio to the Prevention of Bankruptcy in Cigarette Manufacturing Companies Sub Sector. Solid State Technology, 63(3), 4173-4182. http://solidstatetechnology.us/index.php/JSST/article/view/3058

Angelina, S., \& Nugraha, N. M. (2020). Effects of Monetary Policy on Inflation and National Economy Based on Analysis of Bank Indonesia Annual Report. Technium Social Sciences Journal, 10(1), 423-435. https://doi.org/10.47577/tssj.v10i1.1300

Arikunto, S. (2005). Prosedur Penelitian: Suatu Pendekatan Praktik. Yogyakarta: Rineka Cipta.

Ayunitha, A. et al. (2020). Does the Good Corporate Governance Approach Affect Agency Cost? Solid State Technology, 63(4), 3760-3770. http://solidstatetechnology.us/index.php/JSST/article/view/3199

Brigham, E. F., \& Houston, J. F. (2011). Dasar-dasar Manajemen Keuangan Terjemahan Edisi 10. Jakarta: Salemba Empat.

Chasanah, A. N., \& Adhi, D. K. (2018). Profitabilitas, Struktur Modal dan Likuiditas pengaruhnya terhadap Nilai Perusahaan pada Perusahaan Real Estate yang listed di BEI tahun 2012-2015. Jurnal Ilmiah Ekonomi, 12(2), 109-128.

Endarwati, R. D., \& Hermuningsih, S. (2019). Pengaruh Struktur Modal Dan Pertumbuhan Penjualan Terhadap Nilai Perusahaan Dengan Profitabilitas Sebagai Variabel Intervening Pada Perusahaan Properti Dan Real Estate Yang Terdaftar di BEI Tahun 2013-2017. SEGMEN Jurnal Manajemen Dan Bisnis, 15(1).

Febriana, E., \& Djawahir, A. H. (2016). Pengaruh Struktur Modal, Kebijakan Dividen, Ukuran Perusahaan, Kepemilikan Saham Manajerial dan Profitabilitas Terhadap Nilai Perusahaan (Studi pada Perusahaan Manufaktur yang Terdaftar di BEI Pada 2011-2013). Ekonomi Bisnis, 21(2), 163-178.

Ghozali, I. (2011). Aplikasi Analisis Multivariate Dengan Program SPSS. Semarang: Universitas Diponegoro.

Gitman, I. (2012). Principles of managerial finance 13th edition. Massachusetts: Addison-Wesley Publishing Company.

Hardiana, A. T., Wijaya, A. L., \& Amah, N. (n.d.). Pengaruh Perputaran Modal kerja Terhadap Nilai Perusahaan Dengan Profitabilitas Sebagai Variabel Moderasi. In SIMBA: Seminar Inovasi Manajemen, Bisnis, Dan Akuntansi, Vol. 1.

Hirdinis, M. (2019). Capital structure and firm size on firm value moderated by profitability. International Journal of Economics and Business Administration, 7(1), 174-191.

Indriyani, A., Paramita, P. D., \& Ariesta, M. (2018). Pengaruh Perputaran Modal Kerja Dan Net Profit Margin (NPM) Terhadap Nilai Perusahaan Dengan Profitabilitas Sebagai Variabel Moderating Pada Perusahaan Farmasi Yang Terdaftar Di Bursa Efek Indoneisa Periode 2012- 
2016. Journal Of Accounting, 4(4).

Kasmir. (2014). Analisis Laporan Keuangan, Edisi Satu, Cetakan Ketujuh. Jakarta $\square$ : Raja Grafindo Persada.

Nariswari, T. N., \& Nugraha, N. M. (2020). Profit Growth $\square$ : Impact of Net Profit Margin, Gross Profit Margin and Total Assests Turnover. International Journal of Finance \& Banking Studies (2147-4486), 9(4), 87-96. https://doi.org/10.20525/ijfbs.v9i4.937

Nugraha, N. M., \& Riyadhi, M. R. (2019). The Effect of Cash Flows, Company Size, and Profit on Stock Prices in SOE Companies Listed on Bei For the 2013-2017 Period. International Journal of Innovation Creativity and Change, 6(7), 130-141. https://www.ijicc.net/index.php/volume-6-2019/60-vol-6-iss-7

Nugraha, N. M., Fitria, B. T., Puspitasari, D., \& Damayanti, E. (2020). Does Earning Per Share (EPS) Affected By Debt To Asset Ratio (DAR) And Debt To Equity Ratio (DER)?. PalArch's Journal of Archaeology of Egypt/Egyptology, 17(10), 1199-1209.

Nugraha, N. M., Nugraha, D. N. S., \& Sapitri, S. (2020). The Effect of Funding, Investment and Dividend Policies on Firm Value in the Manufacturing Industry Sectors. Solid State Technology, 63(3), 3858-3868.

Nuryaman \& Veronica, C. (2015). Metodologi Penelitian Akuntansi dan Bisnis. Bogor: Ghalia Indonesia.

Octavia, D., \& Nugraha, N. M. (2020). Pengaruh Keputusan Investasi, Keputusan Pendanaan, Dan Kebijakan Dividen Terhadap Nilai Perusahaan Pada Sektor Aneka Industri Yang Terdaftar Di Bursa Efek Indonesia Periode 2014-2018. Jurnal Computech \& Bisnis, 14(1), 01-09. https://doi.org/10.5281/zenodo.3928952

Pratama, I. G. B. A., \& Wiksuana, I. G. B. (2016). Pengaruh ukuran perusahaan dan leverage terhadap nilai perusahaan dengan profitabilitas sebagai variabel mediasi. E-Jurnal Manajemen Universitas Udayana, 5(2).

Pratiwi, N. P. Y., Yudiaatmaja, F., \& Suwendra, I. W. (2016). Pengaruh struktur modal dan ukuran perusahaan terhadap nilai perusahaan. Jurnal Manajemen Indonesia, 4(1).

Qotrotul, R., Adnansyah, I., \& Nugraha, N. M. (2021). Pengaruh Skill Dan Pemberian Insentif Terhadap Kinerja Karyawan RSUD Dr. Soekardjo Tasikmalaya. Jurnal Teknologi Dan Manajemen Industri, 7(1).

Sihombing, M. A., Hutagalung, D. N., Siska, N., \& Sakuntala, D. (2020). Pengaruh Intellectual Capital, Earning per share, dan Leverage terhadap Nilai Perusahaan Food and Beverage di Bursa Efek Indonesia. Owner: Riset Dan Jurnal Akuntansi, 4(2), 257-272. https://doi.org/10.33395/owner.v4i2.233

Siregar, M. E. S., Dalimunthe, S., \& Safri, R. (2019). Pengaruh Profitabilitas, Ukuran Perusahaan, Kebijakan Dividen, Dan Struktur Modal Terhadap Nilai Perusahaan Pada Perusahaan Manufaktur Yang Terdaftar Di Bursa Efek Indonesia Periode 2015-2017. JRMSI-Jurnal Riset Manajemen Sains Indonesia, 10(2), 356-385.

Soebiantoro, U. (2007). Pengaruh struktur kepemilikan saham, leverage, faktor intern dan faktor ekstern terhadap nilai perusahaan. Jurnal Manajemen Dan Kewirausahaan, 9(1), 41-48.

Sugiyono. (2017). Metode Penelitian Kuantitatif, Kualitatif, dan R\&D. Bandung: Alfabeta.

Supardi, S. et al. (2021). Peluang Dan Perubahan Cara Berfikir Saat Pandemik (Pengabdian Kepada UMKM Binaan Kadin Provinsi Jawa Barat). Jurnal Pengabdian Dharma Laksana, 3(2), 162 168.

Suryandani, A. (2018). Pengaruh Pertumbuhan Perusahaan, Ukuran Perusahaan, dan Keputusan Investasi Terhadap Nilai Perusahaan Pada Perusahaan Sektor Property Dan Real Estate Di BEI. Business Management Analysis Journal (BMAJ), 1(1), 49-59.

Susanti, N., Widajatun, V. W., Aji, M. B., \& Nugraha, N. M. (2020). Implications of Intellectual Capital Financial Performance and Corporate Values (Studies on Goods and Consumption Sector 2013-2017 period). International Journal of Psychosocial Rehabilitation, 24(7), 65886599. https://doi.org/10.37200/IJPR/V24I7/PR270623

Susanti, N. et al. (2021). How To Upgrade Your Business Facing The Pandemic Covid-19 (Mengubah Petaka Menjadi Peluang) Pada UMKM Binaan Kadin Provonsi Jawa Barat. Jurnal Pengabdian Dharma Laksana, 3(2), 124-130. 
Owner: Riset \& Jurnal Akuntansi

e-ISSN : 2548-9224 |p-ISSN : 2548-7507

Volume xx Nomor xx, Bulan Tahun

Susyana, F. I., \& Nugraha, N. M. (2021). Pengaruh Net Profit Margin, Return On Assets, dan Current Ratio Terhadap Pertumbuhan Laba. JEMPER (Jurnal Ekonomi Manajemen Perbankan), 3(1).

Sutrisno. (2013). Manajemen Keuangan Teori, Konsep dan Aplikasi. Jakarta $\square$ : Ekonisia.

Taohid, M. G. R., Sujai, R. A. D. A., \& Nugraha, N. M. (2021). Does Work Discipline Affected By The Working Environment And Work Motivation?. Economics. Ecology. Socium, 5(1).

Widajatun, V. W., Nugraha, N. M., \& Ichsani, S. (2019). Kejadian Aksi Teroris Dan Dampaknya Pada Performa Nilai Tukar Dolar Amerika dan Performa IHSG. Jurnal Muara Ilmu Ekonomi Dan Bisnis, 3(1), 141-155. https://doi.org/10.24912/jmieb.v3i1.3415

Widajatun, V. W., Rahmadzikrishafira, T. F., Nugraha, N. M., \& Susanti, N. (2020). Effect of Profitability on Firm Values With Managerial Ownership As a Variable Control (Construction and Building Sub Sector Listed in the Indonesia Stock Exchange for the 2014-2018 Period). International Journal of Psychosocial Rehabilitation, 24(7), 7220-7229. https://doi.org/10.37200/IJPR/V24I7/PR270690

Wijaya, J. H., \& Nugraha, N. M. (2020). Peramalan Kinerja Perusahaan Perbankan Tahun 2017 Yang Terdaftar Di Bursa Efek Indonesia Dengan Metode ARCH-GARCH. BISMA: Jurnal Bisnis Dan Manajemen, 14(2), 101-108. https://doi.org/10.19184/bisma.v14i2.17512

Zulganef. (2018). Metode Penelitian Bisnis dan Manajemen. Bandung: PT Refika Aditama. 